\title{
Impact of Advertising and Sales Promotion Expenses on the Sales Performance of Indian Telecommunication Companies
}

\author{
Joshi Sujata, Prabhu Sandeep and Chirputkar Abhijit \\ Symbiosis Institute of Telecom Management, Constituent of Symbiosis International University, Lavale, \\ Pune 412115, Maharashtra, India; sjoshi@sitm.ac.in, sprabhu@sitm.ac.in, dydirector@sitm.ac.in
}

\begin{abstract}
Objectives: To investigate the relationship between two marketing communication activities mainly advertising and sales promotion on the sales performance of Telecom companies. Methods/Statistical Analysis: Data related to Advertising and Sales promotions expenses of 3 telecom companies for the past 10 years was collected from their annual reports. Multiple regression analysis is used for modelling the relationship between the dependent variable i.e. Net sales and the independent variables of Advertising and Sales promotion activities. Findings: The findings suggest that there exists a significant predictive relationship of advertising spend and sales promotion spends with sales performance of Indian Telecom Companies. The study also proposes a significant model with good predictive power for future use for managers. Application/Improvements: The study will help the telecom operators find out if the spend on advertising, sales promotion and other marketing activity is leading to revenue generation. It will also help them decide an optimal marketing communication mix which will result in better sales performance and thereby increase revenues for the company.
\end{abstract}

Keywords: Advertising, Multiple Regression Analysis, Optimal Marketing Mix, Sales Performance, Sales Promotion, Telecommunication.

\section{Introduction}

The Telecommunication sector in India is a high growth sector. Currently it is ranked $2^{\text {nd }}$ largest telecommunication market in the world with a subscriber base of 1,058.86 million at the end of March-2016. India also has the second largest telecommunications network in the world on the basis of the total sum of users for fixed and mobile telephone services ${ }^{2}$. The main sectors in the telecommunication market of India are Internet, Telephony, and Television broadcast. As a result of market liberalization post 1990, large population base backed by increasing demand and huge development potential of the country, the Indian telecom sector has attracted many players making the competition very stiff in this sector 3 . 4. The major Indian telecom companies are Idea, Bharti Airtel, Vodafone, Reliance Communications, Reliance
Industries Ltd, Aircel, BSNL, MTNL, Tata, Telenor, Sistema, Videocon, and Quadrant.

As a result of the cutthroat competition it has become very essential for the telecom operators to be at the top of the mind recall of the consumer minds. If we watch various television channels, we will find the advertisement of any one or the other telecom company being showcased on the channel. Advertising and Sales promotion have always been a major marketing expense for all telecom organizations. The telecom companies are already bleeding as far as revenue and profits are concerned as a result of high spending on infrastructure, reduced tariff rates, price wars, spectrum auction expenses, mobile number portability etc. Despite that the Telco's continue to spend heavily on marketing and advertising expenditure. With the launch of $4 \mathrm{G}$ services, this sector will

*Author for correspondence 
see the telecommunication providers plan their spent on advertising and marketing $\underline{5}$

Bharti Airtel, ended up spending more than Rs 11,000 crore in advertising in the period between January 2011 and June 2012 which resulted in adding 3.48 crore customers. The intriguing part to be noted is although Airtel's spend on advertisement in quarter of June 2012 rose by $22 \%$, its quarter to quarter subscriber base rose by only $10 \%$. Tata DoCoMo with Ranbir Kapoor as their brand ambassador has spent approximately Rs 400 crore on advertisement, and other marketing expenses. But what can be noted is, 4 million of its customer base has been lost in the six month period between January 2011 to June 2012. Idea Cellular, on the contrary, cut down on its advertisement expenditure which resulted in adding approximately 3.48 crore subscribers (similar to Bharti Airtel) and at one-third the cost of Bharti Airtel's expenditure in the six month period of January 2011 to June 2012.

\section{Objective of the Research}

As a result of the cutthroat competition in the Indian telecom Sector, the telecom operators are spending huge amount of money on marketing communication activities in order to attract and retain the customers. According to Deloitte, with the advent of the $4 \mathrm{G}$ services in India, there is expected to be a boost in the advertising industry by 10 to $15 \% .^{?}$ As per the reports by GroupM media agency, the telecom sector is expected to contribute $6 \%$ to this advertising expenditure in $2016 . \stackrel{8}{\text { In case }}$ of a telecom operator, since the most of the activities are outsourced, the main intangible asset is a customer base. All the operators are trying to gain more customer bases since it is directly linked to higher revenue. To gain more customer base, telecom operators are spending huge amount on advertising and marketing including customer acquisition cost.

So the question which arises is, in the current scenario, when the telecom sector is facing so many problems with respect to capital and operating expenditure, are such lavish expenses in advertising and marketing really justified? The authors have tried to address this research question in the current research paper.

Hence the objective of the current study is to investigate the relationship between two marketing communication activities mainly advertising and sales promotion on the sales performance of Telecom companies.

\section{Literature Review}

\subsection{Advertising}

Organizations today have to make themselves visible as a result of the huge amount of competition present in the market. The Indian telecom industry is no exception to this. As a result of liberalization policy of the government and foreign direct investment being allowed in this sector, multinational companies have joined the competition. India has a large population and is still a developing market for telecom services hence large corporate houses have entered this sector making the competition cutthroat. With the presence of 8 to 10 operators in various circles fighting for the same pie, it has become very essential for the telecom service providers to make themselves visible to the customer. Advertising has become a necessity not just to become visible but to create top of the mind recall and brand equity creation. Hence we see all the telecom service providers investing huge amount of money in advertisements.

According to", "Advertising is paid-for communication to more than one person, intended to inform or change behaviour." According to $\frac{10}{}$, "It is a mediated form of communication from an identifiable source, designed to persuade the receiver to take some action, now or in the future." $\underline{11}$ defined advertising as "the aim to persuade people to buy". As opined by 12 , "Advertising consists of all the activities involves in presenting to a group, a non-personal, oral or visual, openly sponsored message regarding disseminated through one or more media and is paid for by an identified sponsor." As per $\frac{13}{3}$, "Advertising is any paid form of non-personal presentation and promotion of ideas, goods, or services by an identified sponsor". Various studies have showcased the importance and benefits of advertising to organizations to sell their products/services. Advertising creates awareness in consumer mind ${ }^{14}$, enhances buyer response ${ }^{15}$, persuades consumer to buy ${ }^{\frac{16}{}}$, induces customers to buy instead of competitors

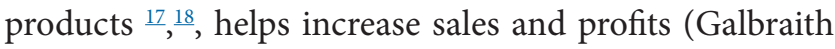
1963) $\frac{19}{}$, creates positive brand associations, $\frac{20}{2}, \underline{21}, \underline{22}, \underline{23}$ create selective demand ${ }^{24}$ and influences brand beliefs and choice ${ }^{25}$. Few studies have pointed out that higher spending on advertising leads to higher awareness $\stackrel{26}{2} ; \underset{27}{20}$ ) and highly advertised brands creates a perception of better quality. $\left(\frac{26}{28}\right)$. Very few studies have been carried out in the telecommunication sector, especially in the context of Indian telecommunication companies; with respect to the impact of advertising spend on sales performance. 


\subsection{Sales Promotion}

Sales promotion is also an important component of the marketing communication mix and extensively used by companies to induce people to buy their product/services. Sales promotion can be monetary (discounts,) or non-monetary (free gifts, sweepstakes, free samples) in nature. Telecom companies in India are extensively using sales promotion techniques in order to incentivize the retailers, distributors, and customers to promote and buy their products/services.

Advertising Standard Authority's (ASA), have defined sales promotion as, "Those marketing techniques which are used, usually on a temporary basis to make goods and services more attractive to the consumers by providing some additional benefit whether in cash or in kind." According to ${ }^{29}$ sales promotion is one of the techniques of conveying information about a product. According to $\stackrel{30}{n}$ sales promotions is "a short-term promotional activity designed to stimulate consumer buying or cooperation from distributors and other members of the trade". According to ${ }^{29}$ sales promotion is "the array of short-term promotional techniques that marketers use to stimulate an immediate purchase" As per $\frac{31}{1}$, sales promotion is "an activity that act as a direct inducement, offering added value or incentive for a product to resellers, salesperson or customers." Several studies have showcased the importance of Sale promotion to organizations. Sales promotion affects consumer purchase decision and brand choice ${ }^{32}$; maximizes sales value, affects sales, profitability and brand equity $\left(\underline{33}, \underline{34}, \frac{35}{5}\right)$, helps to communicate information $\left(\frac{36}{3} ; 37\right)$.enhances desirability $\stackrel{38}{~}$. Thus from the above literature sales promotion comes out as an essential element in the communication mix for organizations. There is a controversial thought on the impact of sales promotion since some studies believe it has a significant effect on effectiveness of an organization ( $\underline{39} \underline{40})$. Whilst others believe that it does not have a significant effect. $(\underline{41} ; \underline{42} ; \underline{43})$

However, it is observed that very few studies have been carried out in the telecommunication sector, especially in the context of Indian telecommunication companies; with respect to the impact of sale promotion spend on sales performance. Hence the authors have arrived at the below mentioned hypotheses based on the literature review.

\subsection{Hypotheses Formulation}

Based on the literature review the relationships between advertising spend and sales promotions spend with sales performance is expressed as following alternative hypotheses.

$\mathrm{H}_{11}$ : There is a significant predictive relationship of advertising spends with sales performance of telecom companies. $\left(\beta_{11} \neq 0\right)$

$\mathrm{H}_{12}$ : There is a significant predictive relationship of sales promotion spends with sales performance of telecom companies. $\left(\beta_{12} \neq 0\right)$

\subsection{Research Methodology}

The Indian telecom sector consists of 11 telecom operators ${ }^{44}$. For the purpose of data analysis for this study financial data was required related to the advertising and sales promotion expenses of the telecom operators. Hence secondary form of research was adopted for collection of this financial data from the annual reports of the companies. Out of the 11 operators, 8 operators have invested in spectrum auction and commenced operation. Out of these 8 operators the financial data related to advertising and sales expenses was available only for 3 telecom operators viz. Bharti Airtel Ltd, Idea cellular limited and Tata Teleservices Ltd since they are already listed on the stock exchange and the data is available in their Annual report. Thus for the purpose of our study we have selected these three listed companies. The advertising, sales promotion expenses and sales revenue data for the past 10 years was collected for the above mentioned three companies in India from published balance sheets. So a total sample size of 30 was available for data analysis.

Considering the predictive nature of the study, descriptive analysis technique in the form of regression analysis was used for analysing the data. Multiple regression model is considered to be a suitable analysis considering predictive nature of the data. The quantitative study involves descriptive analysis and involves longitudinal data. As discussed earlier, the secondary data is collected from published annual reports of telecom companies. The sample element is an annual performance report of telecom companies. In addition a predictive regression model is proposed to be developed for future use.

\subsection{Analysis Results and Hypotheses Testing}

Significance of above hypothesis $H_{1}$ and $H_{2}$ and the model is tested using multiple regression. Considering advertising spends and sales promotions spend as predictor variables and sales performance as predicted following multiple regression output is obtained. 
Table 1. Model Summaryb

\begin{tabular}{|c|c|c|c|c|}
\hline Model & R & R Square & Adjusted R Square & Std. Error of the Estimate \\
\hline 1 & $.950^{\mathrm{a}}$ & .902 & .894 & 5487.82260 \\
\hline \multicolumn{5}{|c|}{ a. Predictors: (Constant), Sales promotion expenses, Advt.expenses } \\
\hline \multicolumn{5}{|c|}{ b. Dependent Variable: Sales (Net) } \\
\hline
\end{tabular}

Table 2. ANOVA $^{\underline{a}}$

\begin{tabular}{|c|c|c|c|c|c|c|}
\hline \multicolumn{2}{|c|}{ Model } & Sum of Squares & df & Mean Square & F & Sig. \\
\hline \multirow{3}{*}{1} & Regression & 7446452106.698 & 2 & 3723226053.349 & 123.629 & $.000^{\mathrm{b}}$ \\
\cline { 2 - 7 } & Residual & 813137314.722 & 27 & 30116196.842 & \\
\cline { 2 - 7 } & Total & 8259589421.420 & 29 & & \\
\hline \multicolumn{6}{|c|}{ a. Dependent Variable: Sales (Net) } \\
\hline \multicolumn{6}{|c|}{ b. Predictors: (Constant), Sales promotion expenses, Advt.expenses } \\
\hline
\end{tabular}

Table 3. Coefficients ${ }^{\mathrm{a}}$

\begin{tabular}{|c|c|c|c|c|c|c|c|c|}
\hline & \multirow{2}{*}{ Model } & \multicolumn{2}{|c|}{ Unstandardized Coefficients } & \multirow{2}{*}{$\begin{array}{c}\begin{array}{c}\text { Standardized } \\
\text { Coefficients }\end{array} \\
\text { Beta }\end{array}$} & \multirow{2}{*}{$\mathrm{t}$} & \multirow{2}{*}{ Sig. } & \multicolumn{2}{|c|}{ Collinearity Statistics } \\
\hline & & B & Std. Error & & & & Tolerance & VIF \\
\hline \multirow{3}{*}{1} & (Constant) & -4440.933 & 1966.944 & & -2.258 & .032 & & \\
\hline & Advt.expenses & 38.993 & 8.594 & .508 & 4.537 & .000 & .291 & 3.436 \\
\hline & $\begin{array}{l}\text { Sales promotion } \\
\text { expenses }\end{array}$ & 11.827 & 2.750 & .481 & 4.301 & .000 & .291 & 3.436 \\
\hline \multicolumn{9}{|c|}{ a. Dependent Variable: Sales (Net) } \\
\hline
\end{tabular}

F statistics of the multiple regression model is highly significant (sig. 000) indicating good model fit. The difference between R-square and adjusted R-square $(0.88 \%)$ is far less than $10 \%$ also indicating good model fit. R-square value indicate $90.2 \%$ variation in sales performance can be explained by combined effect of advertising and sales promotion spent; indicating good predictive power of the model.

Advertising spent is significant variable $(\mathrm{t}=4.537$, sig.0.000) contributing to the model. Sales promotion $(t=4.301$, sig. 0.000$)$ is also a significant variable contributing the model. Both the values of variance inflation factor (VIF) values are less than 1 , indicating no multicollinearity issues with variables.

The predictive relationship can be expressed as a predictive model as follows;

Sales $=-4440.933+38.993 \times$ Ad spent $+11.827 \times$ Sales promotion

\section{Limitations of the Research}

This study has taken into consideration 3 telecom companies which were listed and the advertisement and sales promotion expenses were revealed in the annual reports. The information of other telecom companies (other than these 3) was not available. As these remaining companies are not listed hence their authentic financial information is not available. . The last ten years data of these 3 companies related to sales, advertisement spend and sales promotion spend has been collected based on the balance sheets of the companies as appearing in their annual reports. This small sample size of 30 has limited scope to generalization.

\section{Managerial Implications}

This study discusses two important aspects of marketing communication mix namely advertising and sales promotion and its impact on the sales performance of the telecommunication companies. As discussed in our literature review there are controversial beliefs on the impact of these two constructs on sales performance. Some studies claim there is a significant impact whereas other studies believe that here is no significant impact of advertising and sales promotion on sales performance. Also as 
suggested in literature review very few studies have been conducted in the telecommunications sector especially in the Indian context with respect to the above.

In case of telecom operators, customer base is important and has direct impact on revenue, profits and valuation. Thus the telecom operators have two options i.e. to acquire customer base which is called as customer acquisition cost or carry out more of a branding and advertising to acquire more customers. The data related to first strategy / option is not available for all operators however we have mentioned the co-relation in case of option two. This will help operators to decide strategy of having more customer base to maximize profit in long run.

This study reveals that there is a significant predictive relationship of advertising spends with sales performance of telecom companies. It also shows that there is a significant predictive relationship of sales promotion spends with sales performance of telecom companies. The study proposes a statistical model to predict sales revenue for varying amounts of advertisement spent and promotion spent. The model can be useful for better forecasting of sales revenue for planned ad and promotion expenses.

This study proves that it is justifiable for telecom companies to spend on advertising and sales promotion since it is resulting in revenue generation. The study will also help marketing managers to decide an optimal marketing communication mix which will result in better sales performance and thereby increase revenues for the company.

\section{References}

1. Article http://www.trai.gov.in/WriteReadData/PIRReport/ Documents/Indicator_Report_05_August_2016.pdf Date accessed: 05/10/2016.

2. Article Economic Times. India needs umbrella body on telecom: Date Accessed: 16/08/2012.

3. Article Dharma Kumar, Rohin. India Telco's: Battle of the Titans: Forbes.2011. Date Accessed: 19/08/2011.

4. Article Kannan, Shilpa. India's $3 \mathrm{G}$ licence bidders bank on big changes. (Internet)BBC News: 2010. Date Accessed: 01/10/2010 http://news.bbc.co.uk/2/hi/business/8607866.stm

5. Article Vidhi Choudhary. Ad spending seen growing at $15.5 \%$ in 2016 , driven by digital. Livemint E-paper. Date Accessed: 18/09/2016.

h t t p : / / w w w. live mint.com/Cons u m e r / LjI3ZO4nYkN8DNdyMIlJlJ/Ad-spending-to-grow-at-155in-2016-higher-than-2015s-14.html
6. Article Riken Mehta. Are massive ad spends by telecom companies truly justified? Moneycontrol.com 2012. Date Accessed:05/10/2016http://www.moneycontrol.com/news/ market-edge/are-massive-ad-spends-by-telecom-companies-truly-justified_747060.html?utm_source=ref_article,

7. Article Economic Times. Telco's $4 \mathrm{G}$ push to help advertising sector grow 15\% in 2016. Date Accessed: 11/11/2016 http://articles.economictimes.indiatimes.com/2016-01-03/ news/69486476_1_advertising-industry-4g-services-pitchmadison-media-advertising-outlook

8. Article Business Standard Reporter. Ad spend in India to grow at $15.5 \%$ in 2016 says Group M. January 2016. Date Accessed: 11/11/2016 http://www.business-standard.com/ article/companies/ad-spend-in-india-to-grow-at-15-5-in2016-says-groupm-116012000014_1.html

9. Broadbent, S. Advertising. In M. J. Baker (ed.). The IEBM encyclopaedia of marketing. London: International Thomson Business Press; 2001.

10. Richards JI, and Curran CM. Oracles on advertising searching for a definition. Journal of Advertising. 2002. 31(2). p. 63-77.

11. Frank J. Advertising. Pearson Education Limited, UK;2005

12. Etzel MJ, Walker BJ, and Stanton WJ. Marketing. Boston: McGraw-Hill/Irwin.2007.

13. Kotler P. and Armstrong G. Principles of Marketing (12th edition). Prentice Hall of India.2010

14. Morden AR. Elements of Marketing. London: D.P.1991

15. Kotler P. Marketing Management: Analysis Management and Accounting. Ile-Ife: Obafemi. 1988

16. Frank J. Advertising. Pearson Education Limited, UK;2005

17. Young CE. The Advertising Handbook, Ideas In flight, Scattle, W.A., ISBN 0- 9765574-0-1g7; 2005

18. Richards JI, and Curran CM. Oracles on advertising: Searching for a definition. Journal of Advertising.2002. 31(2):63-77.

19. Galbraith JK. The Affluent Society, New York: New American Library, (First Published in 1958). 1976

20. Cobb-Walgren C, Ruble CA, Donthu N. Brand equity, brand preference and purchase intent. Journal of Advertising. 1995; 24(3):25-40

21. Moorthy S, Hawkins SA. Advertising repetition and quality perception. Journal of Business Research. 2005. 58(3):354-60

22. Keller KL. Strategic brand management: Building, measuring, and managing brand equity. (3). New Delhi: Dorling Kindersley.2008.

23. De Chernatony L. From brand vision to brand evaluation. The strategic process of growing and strengthening brands. 3rd Ed. Butterworth Heinemann; 2010.

24. Arens WF. Contemporary advertising (Vol. 8). New York: McGraw-Hill/Irwin.2002

25. Shimp TA. Integrated marketing communications in advertising and promotion (Vol. 7). Mason: $\mathrm{OH}$, Thomson Higher Education.2007 
26. Yoo B, Donthu N, Lee S. An examination of selected marketing mix elements and brand equity. Journal of the Academy of Marketing Science. 2000; 28(2):195-211.

27. Villarejo AF, Sánchez MJ. The impact of marketing communication and price promotion on brand equity. Journal of Brand Management 2005; 12(6):431-45.

28. Bravo R, Fraj E, Martínez E.Family as a source of consumer-based brand equity. The Journal of Product and Brand Management. 2007; 16(3):188-99.

29. Blanchard K, Schewe C, Nelson R. and Hiam A. Exploring the World of Business. USA: Worth Publishers, Inc.1999

30. Griffin RW and Pustay MW. International Business by Griffin and Pustay (5th, Fifth Edition). 2007

31. William, Ferrel, Pride M, (1994) Marketing Research (New York, McCarthy and Engle et al 1991).

32. Nijs VR, Dekimpe MG, Steenkamps JBE. and Hanssens DM. The category demand effects of price promotions. Marketing Sciences. 2001; 20 (1):1-22

33. Srinivasan SS, Anderson RE.Concepts and strategy guidelines for designing value enhancing sales promotions. The Journal of Product and Brand Management. 1998; 7(5):410-20.

34. Palazón-Vidal M, Delgado-Ballester E. Sales promotions effects on consumer-based brand equity. International Journal of Market Research. 2005; 47(2):179-204.

35. Montaner T, Pina JM. The effect of promotion type and benefit congruency on brand image. Journal of Applied Business Research. 2008; 24(3):15-28.
36. Pride K. Sales and Relationships Manager at Rainbow Tourism Group Senior sales manager Rainbow Tourism Group - Zimbabwe, Zambia, Mozambique. 1987

37. Ricky W, Ebert J. and Starke and A. Business: 5th Canadian ed. Canada: Pearson Education Canada Inc., Toronto, Ontario.2005

38. Griffin RW and Pustay MW. International Business by Griffin and Pustay (5th, Fifth Edition). 2007

39. Boddewyn JJ and Leardi M. Sales Promotions: Practice, Regulation and Self-Regulation around the World. International Journal of Advertising. 1989; 8(4):363.

40. Odunlami IB, Ogunsiji A. Effect of sales promotion as a tool on organizational performance. Journal of Emergency. Trends in Economics and management Sciences. (JETEMS). 2011; 2(1): 9-13.

41. Dekimpe MG, et al. Long run effects of price promotion in scanner markets. Journal of econometrics. 1999; 89:269-291.

42. Srini S, Srinivasan SS and Anderson RE. Concepts and strategy guidelines for designing value enhancing sales promotions. Journal of Product and Brand Management. 2000; 20007, 5:410-420.

43. Pauwels K, Hanssens DM, and Siddarth S. The Long Term Effects of Price Promotions on Category Incidence, Brand Choice and Purchase Quantity. Journal of Marketing. 2002. p. 27-29.

44. Article TRAI report Highlights of Telecom Subscription Data as on 31st July, 2016 (PDF). TRAI.2016 (Internet). Date Accessed: 11/11/2016 https://en.wikipedia.org/wiki/ Mobile_network_operators_of_India 